\title{
Игорь Максимычев
}

\section{Конец меркелевской Европы? О предстоящем завершении одной политической карьеры}

\begin{abstract}
Аннотачия. Автор анализирует особенности политической биографии, основные приоритеты и итоги деятельности А. Меркель. Как во внутриполитической, так и в международной сфере результаты приближающейся к завершению «эры Меркель» представляются противоречивыми. Положение ФРГ в качестве неформального лидера Евросоюза приносит стране не только выгоды, а ее образ в глазах партнеров ухудшается с каждым годом. Заметно обострился вопрос о месте Германии в глобальной политике, и прежде всего о характере ее взаимоотношений с Россией.
\end{abstract}

Ключевые слова: Ангела Меркель, эра Меркель, политическая жизнь Германии, германская внешняя политика, лидерство Германии, российско-германские отношения.

$\longrightarrow$

олитик, личность которого долго находилась в центре общественного внимания, всегда рискует в случае очередной неудачи мгновенно утратить популярность и даже стать объектом нелицеприятной критики. Лишь немногим удается проститься с властью, сохранив такое достоинство и уважение, как Шарль де Голль (с которым это случилось дважды). Яркий пример противоположного свойства явил обожествлённый своими дальними потомками Наполеон Бонапарт - его после финального поражения при Ватерлоо едва не растерзала толпа собственных подданных. Не будет гладким и спуск с властных вершин для долголетнего канцлера ФРГ Ангелы Меркель.

А. Меркель останется в истории политиком, которому суждено было присутствовать при крушении самых заветных своих проектов. Но поскольку цели госпожи канцлера очень часто входили в клинч с интересами и чаяниями людей в Германии, а также в других странах Евросоюза и на континенте в целом, у европейцев отсутствуют причины рвать на себе волосы по случаю завершения «эпохи Меркель».

\section{Синдром отличницы}

У психологов есть понятие «синдром отличника» (или «синдром отличницы», так как он чаще наблюдается у женщин) - близкое, но не совсем тождественное термину «перфекционизм». Обладатель этого синдрома считает свою задачу полностью выполненной, только когда сделанная работа заслуживает самого высокого балла, даже если за

Сведения об авторе: Максимычев Игорь Федорович - главный научный сотрудник Института Европы РАН, доктор политических наук; igorfedmax@yandex.com. 
отсутствием «начальника» приходится выставлять эту оценку самому. Вышеуказанное качество, в целом похвальное, зачастую приводит, однако, к отрицательным последствиям. Оно порождает, например, высокомерие по отношению к окружающим («Они не способны постоянно получать высшие оценки»), неумение правильно воспринимать критику («Разве допустимы возражения, когда все столь совершенно?»), уверенность в собственной непогрешимости, отказ от исправления допущенных промахов. Человек с синдромом отличника действует, как правило, по принципу «хочешь сделать хорошо - сделай сам». В результате перфекционист перегружает себя второстепенными делами, теряет из виду целостную картину происходящего, отбивает у подчиненных охоту проявлять инициативу. Синдром зарождается в школьные годы, в дальнейшем он усиливается, и со временем преодолеть его становится невозможным.

А. Меркель относится к разряду заядлых отличниц. Она была среди первых учениц в средней политехнической школе в Темплине (ГДР) и выпускные экзамены в 1973 г. сдала, разумеется, с наивысшими оценками. Беспроблемно пройдя курс обучения на физическом факультете Лейпцигского университете имени Карла Маркса, она в 1986 г. с блеском защитила докторскую диссертацию в Центральном институте физической химии Академии наук ГДР в Берлине, где стала работать в отделе теоретической химии. Выделялась способностью легко осваивать иностранные языки, побывала по студенческому обмену в СССР (даже сейчас ей нетрудно произнести несколько фраз порусски).

Для успешной научной карьеры в условиях ГДР непременно требовалось активное участие в общественной жизни. Уже в ранней юности будущий канцлер окунулась в политику, с рвением включившись в работу Союза свободной немецкой молодежи, аналога советского комсомола. В Берлине она была избрана членом райкома ССНМ, секретарем по агитации и пропаганде. Произошло это в преддверии «смутного времени», стартовавшего с подачи горбачевской перестройки, когда под вопросом оказались сами основы существовавшего в социалистических странах общественного строя.

На первых порах явных оппозиционных настроений у Меркель не просматривалось. Однако надо учитывать, что она была выходцем из семьи протестантского пастора, переселившейся в ГДР из ФРГ в 1954 г., через несколько дней после рождения Ангелы. Евангелическая церковь в ГДР была главной опорой поддерживаемого из ФРГ «духовного сопротивления» реальному социализму. Протестанты являлись реальной политической силой, поскольку именно к этой ветви христианства принадлежало большинство населения республики. Католики представляли лишь незначительную его часть, и католические священники сохраняли, как правило, лояльность властям. Организаторы массовых выступлений 1989 г. использовали протестантские церкви - с согласия или даже по инициативе их пасторов - в качестве организационных центров для проведения антиправительственных демонстраций. Перестав быть пастором вскоре после переезда в ГДР, отец Меркель в течение долгого времени сохранял тесную связь с церковными структурами Берлина и Бранденбурга. Царившие в евангелической церкви оппозиционные настроения не могли не повлиять на формирующиеся политические взгляды Ангелы. 
У Меркель не проявилось желания вступить в правившую в ГДР Социалистическую единую партию Германии (СЕПГ) или в другую партию связанного с ней демократического блока. Ангела не помышляла о карьере политика. Оставайся обстановка в ГДР спокойной, подобный шаг на более поздних этапах не был бы исключен, поскольку он обеспечивал карьерный рост. Однако к концу 80-х годов обстановка в ГДР стала стремительно обостряться. Когда размах оппозиционного движения в республике достиг масштабов, которые позволяли сделать вывод о неизбежности скорых фундаментальных изменений в общественном строе ГДР, вопрос об определении своего места в новом раскладе политических сил встал перед Меркель в полный рост.

Переломным моментом в ее жизни - так же как и всей ГДР - стало падение Берлинской стены 9 ноября 1989 г., катастрофические обстоятельства которого были обусловлены рядом непростительных тактических ошибок со стороны руководства СЕПГ [См.: Максимычев, 2011]. Спустя месяц Ангела подключилась к работе одной из новых оппозиционных партий, получившей название «Демократический прорыв», - сначала на технической должности (администратор ЭВМ), а затем в отделе по связям с печатью, став практически пресс-секретарем председателя партии. Обращает на себя внимание, что Меркель приняла решение вступить не в существовавший в ГДР Христианско-демократический союз (ХДС), объединявший католиков и протестантов (что было бы логично с учетом ее семейных традиций), а в организацию без исторических корней, которую поначалу относили к левым течениям. Как участник блока демократических партий, поддерживавшего СЕПГ на протяжении всего периода существования республики, ХДС (ГДР) не пользовался популярностью среди реформаторов, заполонивших политическую сцену страны. Мало кто в ГДР заметил, что к руководству этой партии уже пришли люди, готовившие присоединение республики к ФРГ.

C «Демократическим прорывом» же случился конфуз. Получившие доступ к архивам министерства госбезопасности ГДР спецслужбы ФРГ объявили, что председатель партии Вольфганг Шнур - агент («неформальный сотрудник») штази. Это означало конец его политической карьеры. Погребальный колокол прозвонил и по партийному детищу Шнура, получившему на выборах в Народную палату 18 марта 1990 г. менее одного процента голосов. Победителем выборов стал презираемый реформаторами ХДС республики (41\% голосов). Однако поскольку ХДС и ряд других восточногерманских политических формирований, включая «Демократический прорыв», выступали на выборах в рамках поддержанной канцлером Колем единой коалиции «Альянс за Германию», личный крах Шнура не помешал Меркель получить высокую должность в аппарате нового правительства. Она была назначена заместителем пресс-секретаря премьер-министра, которым стал председатель ХДС (ГДР) Лотар де Мезьер. Ангела присутствовала практически на всех раундах немецко-немецких переговоров об объединении, набивая руку на общении с прессой. Была она и в Москве, когда там 12 сентября 1990 г. подписывался договор «2+4» об условиях объединения Германии.

В том же году при непосредственном участии А. Меркель состоялось присоединение «Демократического прорыва» к ХДС (ее партия вошла прямо в ХДС единой ФРГ, после того как христианско-демократические союзы обоих германских государств слились 
в один). Произошло это в октябре 1990 г. на объединительном съезде в Гамбурге, где произнесенная Меркель торжественная речь, приличествующая столь радостному поводу, произвела соответствующее впечатление.

Освоение профессии политика шло полным ходом. А. Меркель нащупала, наконец, верное направление движения, нашла свое место в правильной партии, закрепилась в поле зрения всесильного Гельмута Коля. «Канцлер германского единства» приметил юную, но старательную поклонницу и взял ее под свое крыло. Ангела стала для всех «девочкой Коля». Началось долгое и в целом весьма успешное восхождение Меркель по ступенькам германской политической лестницы.

\section{На пути к власти}

Г. Коль, начав с глухого провинциального уровня, достиг на протяжении 70-х годов прошлого столетия положения безусловного авторитета в федеральном руководстве ХДС - партии, погрязшей в позиционных боях за возвращение себе статуса правящей. Не выделявшийся особыми талантами Коль сумел задвинуть в тень таких ярких соперников, как Франц-Йозеф Штраус из «сестринского» ХСС, и навечно остался в немецкой истории как объединитель двух германских государств. Сложнейшую задачу присоединения ГДР в 1990 г. Колю удалось решить мирным и неконфронтационным путем, нейтрализовав все возможные возражения со стороны держав, имевших право голоса в германских делах. Как подтверждают историки, им не было допущено ни единой существенной ошибки в процессе ликвидации восточногерманского государства, столь долго осложнявшего жизнь западной коалиции. При этом он сумел остаться в дружеских отношениях и с М.С. Горбачевым, и с Б.Н. Ельциным, хотя это было непростым делом, так как они оба люто ненавидели друг друга.

Но еще более тесные личные отношения, тщательно выстроенные Г. Колем, связывали его с главами западных держав, прежде всего США, чье лидерство он никогда не ставил под сомнение. Канцлер часто использовал возможность телефонных контактов с западными коллегами, решая подчас очень сложные вопросы. Как знать - может быть, заслуживает доверия утверждение Коля, что пары его телефонных звонков хватило бы для предотвращения натовских бомбардировок Югославии, начавшихся в марте 1999 г. [см.: Примаков...; Mit Helmut Kohl...]. Но в тот момент он уже не был канцлером. Пост федерального канцлера занял Герхард Шредер (СДПГ), вице-канцлера - Йошка Фишер («зеленые»).

К этому времени А. Меркель накопила изрядный опыт работы в федеральном правительстве. Решающим и неоценимым фактором ее карьерного успеха изначально была целенаправленная поддержка со стороны Г. Коля. В целом внедрение представителей Восточной Германии в новую общегерманскую политическую элиту, без чего было в принципе невозможно говорить о воссоединении, шло исключительно трудно и сопровождалось всякого рода скандалами - высокопоставленные старожилы отчаянно сопротивлялись дележу пирога. В обстановке всеобщей сумятицы Меркель сумела сохранить свою безупречную репутацию. Она быстро усвоила, что ее «Гэдээровское» 
прошлое - это скорее минус, чем плюс в глазах общегерманского истеблишмента, который по сути ничем не отличался от прежнего западногерманского. Восточногерманская ересь, включая вольномыслие оппозиционеров 1989 г., отвергалась напрочь.

Не оставалось никаких сомнений: любая попытка защищать бывших граждан ГДР, преследуемых за «происки» против «старой» ФРГ, или ссылаться на успешный опыт республики в решении социальных проблем привела бы к немедленной карьерной катастрофе. «Гэдээровское» клеймо подлежало скорейшему радикальному удалению. Впредь отзывы Меркель о ГДР будут только негативными. Миросозерцание «девочки Коля» выровнялось по главным ориентирам, продиктованным западногерманскими политкомиссарами из ХДС/ХСС. Америка - венец творения, быть с ней - гарантия глобального успеха. НАТО навечно обеспечивает безопасность немцев и заодно их ведущие позиции в Европе. Объятия с Францией - необходимая предпосылка результативной внешней политики ФРГ. Европейская интеграция - наиболее надежный способ гарантировать германскую гегемонию на континенте. Рыночное хозяйство - залог всеобщего счастья, все нападки на него - от лукавого. Зло в Европу приходит только с Востока, Россия всегда находится под подозрением, независимо от наличествующей в ней формы правления.

Этих немудреных, но зато бесспорно прозападных ориентиров оказалось вполне достаточно, чтобы Ангелу в партии заметили и оценили по достоинству. Как правило, носители синдрома отличника редко отвлекаются на абстрактные построения и теоретические рассуждения. Они всегда практики, ограничивающие поле зрения проблемами, связанными со скрупулезным исполнением возложенных на них обязанностей. Надо отдать Меркель должное - ни малейших поводов для критики в ее адрес не было. Головокружительно быстрое продвижение к властным вершинам стало логичным следствием.

В январе 1991 г., в свои неполные 37 лет, не имевшая опыта государственной службы и бездетная Ангела стала министром по делам женщин и молодежи в четвертом по счету кабинете Коля - канцлер лично выдвинул ее на этот пост. Коль инициировал и ее избрание заместителем председателя ХДС в декабре 1991 г. взамен ушедшего в отставку Лотара де Мезьера, которого упорно, хотя и бездоказательно, обвиняли в сотрудничестве со «штази». Вскоре А. Меркель осталась практически единственным заслуживавшим внимания выходцем из ГДР на германском политическом Олимпе. Этот формальный момент сильно увеличил ее удельный вес в раскладе соперничающих сил и течений во внутренней политике ФРГ. В 1994 г. она занимает пост министра охраны окружающей среды, который в германских условиях несет значительную политическую нагрузку. И снова к деятельности Меркель нет никаких претензий. Она говорит, думает, решает, поступает как полноценный политик из «старой» ФРГ.

После неудачных для партии парламентских выборов 1998 г. ставшую «безработной» Меркель избирают генеральным секретарем ХДС, а это пост, дающий уникальную возможность влиять на функционирование партийного аппарата. Этот гигантский рывок вперед открывал путь к посту председателя ХДС и теоретически - к связанному с этой 
должностью креслу канцлера. Еще несколько лет назад о таких перспективах молодой берлинский химик и думать не могла. На пути к сияющим политическим вершинам Ангеле предстояло перешагнуть через своего главного благодетеля. Этот акт черной неблагодарности был несколько задекорирован тем, что по ряду причин старейшины ХДС предпочли возложить ответственность за проигранные выборы лично на «несменяемого» Г. Коля. Тому пришлось уйти в отставку с поста председателя партии (для соблюдения приличий он стал лишенным реальной власти «почетным председателем»). Лидером партии избрали его главного внутрипартийного оппонента Вольфганга Шойбле, который и предложил кандидатуру Меркель на должность генерального секретаря. Чуть позже разразился шумный скандал по поводу так называемого «незаконного финансирования» предвыборной избирательной кампании ХДС, по ходу которого Коль отказался назвать имена замешанных в этом спорном деле спонсоров. Со стороны партии было отказано в поддержке его позиции, и он навсегда рассорился с новым руководством ХДС.

Признаков того, что А. Меркель терзалась сомнениями, принимая решение, в чьей лодке плыть, замечено не было. Власть находилась уже на расстоянии протянутой руки. Она публично выступила с призывом к «обновлению» ХДС, который, по ее убеждению, был в состоянии добиться успеха и без Г. Коля. В этот момент, как по заказу, чувствительный удар по престижу получил В. Шойбле: свара в партийной верхушке не прошла для него бесследно, и он был также вынужден уйти в отставку. Меркель осталась на ристалище в гордом одиночестве, и очередной съезд ХДС в апреле 2000 г. избрал ее председателем партии. Однако дожидаться, когда социал-демократы оступятся и ХДС вновь сможет вернуться во власть, пришлось довольно долго.

Тем временем в блоке христианских партий обострилась конкуренция в борьбе за манящий пост канцлера. А. Меркель пришлось на первых порах уступить, и на парламентские выборы 2002 г. ХДС/ХСС вышли под предводительством председателя баварского ХСС Эдмунда Штойбера в качестве кандидата на главную государственную должность. Эти выборы были проиграны. Одной из причин поражения стал пацифистский настрой германской общественности: правящая коалиция СДПГ и «зеленых» отказалась благословить затеянную под фальшивым предлогом войну США в Ираке, в то время как А. Меркель всецело поддержала еe [Merkel verteidigt...]. Впервые столь недвусмысленно проявилась готовность будущего главы германского правительства следовать любым зигзагам американской политики. Вассальная преданность не осталась незамеченной за океаном. Отныне содействие Вашингтона было Меркель обеспечено.

Оппозиционный период карьеры А. Меркель был отмечен также последовательным «выдавливанием» из руководства ХДС потенциальных соперников, способных претендовать на высшие посты в государстве. Наиболее характерным был конфликт с располагавшим значительным влиянием в высших финансовых кругах ФРГ Фридрихом Мерцем, занимавшим перспективный пост председателя объединенной фракции ХДС/ ХСС в бундестаге. Он сделал серьезную заявку на роль теоретика германского консерватизма. Всеобщее внимание привлекла выдвинутая им концепция «ведущей германской культуры» («deutsche Leitkultur»), которая, в противовес распространенной в то 
время в ФРГ теории «симбиоза культур», или мультикультурализма («Multikultur»), исходила из того, что постоянно живущие в Германии иностранцы должны интегрироваться в немецкую культурную среду. Уже тогда проблема взаимоотношений между коренным населением и иммигрантами (по большей части турками) стала приобретать чрезвычайную остроту. Меркель отклонила идею Мерца (хотя сама некоторое время спустя публично признала, что политика «симбиоза культур» потерпела крах). Восстановив партийную традицию, она лично возглавила парламентскую фракцию ХДС/ХСС. Оскорбленный Мерц бросил политику и ушел в большой бизнес.

\section{«Мамочка Меркель»}

Судьбоносный час пробил для А. Меркель в ноябре 2005 г., когда после удачного для ХДС/ХСС исхода парламентских выборов она была большинством голосов депутатов бундестага избрана федеральным канцлером. Для характеристики нового главы правительства была типична превосходная степень: самый молодой канцлер (51 год) за все время существования ФРГ, первая в германской истории женщина на этом посту, первый немецкий канцлер с естественно-научным образованием (остальные были по преимуществу юристами). Наконец, впервые столь важную должность занял выходец из Восточной Германии (пусть даже связь Меркель с ГДР была по существу только формальной).

Парламентская база, на которую опиралось правительство Меркель, была также не совсем обычной для ФРГ. В эту так называемую большую коалицию входили обе наиболее многочисленные («народные», по немецкой терминологии) партии ФРГ. Столь тесное единение ХДС/ХСС и СДПГ наблюдалось в прошлом лишь один раз - в 19661969 гг., когда канцлером был Курт Георг Кизингер (ХДС), а вице-канцлером, министром иностранных дел - Вилли Брандт (СДПГ). На протяжении почти всего остального времени существования ФРГ ее политическая система носила по существу бипартийный характер: ХДС/ХСС и СДПГ были противостоящими полюсами, вокруг которых в той или иной комбинации группировались более мелкие партии. Эксперимент с совместным ведением государственных дел в рамках единой правящей коалиции закончился в конце 60-х годов не совсем удачно для христианских партий. Социал-демократы оттеснили их от властных вершин, договорившись со свободными демократами. Последовал продолжительный (1969-1982 гг.) период социал-демократического (совместно со СвДП) правления. Этот исторический урок требовал от Меркель особой осторожности в общении с партнером-соперником.

Впрочем, к началу XXI в. социал-демократы во многом растеряли свой боевой дух и пробивную силу по сравнению с предшествовавшим героическим периодом реальной борьбы за власть. Партия не располагала более вождями ранга Вилли Брандта или Гельмута Шмидта, его преемника на посту канцлера. Неуемная энергия Герхарда Шредера пугала многих в руководстве СДПГ, привыкшем к спокойному оппозиционному существованию за 16 лет канцлерства Гельмута Коля (1982-1998 гг.). Предлагавшиеся социал-демократами решения возникающих время от времени экономических и внутриполитических проблем ФРГ практически ничем не отличались от рецептов 
ХДС/ХСС и зачастую были больше ориентированы на интересы крупного капитала, чем на нужды средних слоев населения. Тождественность политической платформы обеих «народных партий» стала особенно очевидной в ходе широкомасштабной операции по присоединению ГДР, когда западногерманский политический класс выступал единым фронтом. В условиях объединенной Германии разницу в позициях христианских партий и социал-демократов можно было разглядеть только во внешнеполитической сфере, где определенное влияние сохранял Эгон Бар, творец концепции «новой восточной политики», с которой связано занимаемое В. Брандтом место в европейской истории. Но не внешняя политика определяет по большей части поведение немецкого избирателя.

А. Меркель неплохо справилась с необходимостью убедительно подтвердить преемственность своей политики по отношению к успешному в целом курсу Г. Коля, обозначив в то же время отказ от самолюбования, характерного для «канцлера воссоединения». Молодость не помешала ей вжиться в роль заботливой и методичной хозяйки, занятой прозаическим делом наведения и поддержания порядка в германском, а заодно и в европейском доме. Линия поведения Меркель точно соответствовала правилу, которое находит отклик в душе любого немца, независимо от его социального положения и политических убеждений: «Должен быть порядок» («Ordnung muss sein»). (Некогда стальную, а ныне несколько расшатавшуюся немецкую дисциплину не смогли добить даже гей-парады, на которые собираются нетрадиционные сексуалы со всего континента.)

Готовность «шагать в ногу со временем» А. Меркель демонстрировала в том, что касается покровительства всевозможным меньшинствам, а также следования новейшим веяниям европейской политической моды, типа «ювенальной юстиции». Она первой из глав европейских правительств использовала возможность вещания в интернете, чтобы еженедельно в непринужденной форме кратко информировать население о своих оценках происходящего в стране и за ее пределами, а также о прогнозах на будущее. Вряд ли было случайностью, что свой первый «подкаст» в июне 2006 г. она посвятила проходившему в ФРГ чемпионату мира по футболу. Футбол - это практически общенациональная страсть немцев. Обращение к слушателям в стиле общения футбольных фанатов послужило лучшей демонстрацией близости нового канцлера к народу. Язык публичных выступлений Меркель был нарочито прост и понятен для каждого. В целом она сумела подобрать верный ключик к сердцу немецкого обывателя. Постепенно за ней закрепилось чуть-чуть ироническое, но по существу исполненное сердечной симпатии прозвище «мамочка» («Mutti»).

Возглавляемый Меркель ХДС стал уверенно увеличивать отрыв от своего главного соперника, которым оставалась СДПГ. Участие социал-демократов в «большой коалиции» на правах младшего партнера неуклонно вело к эрозии голосующего за них сектора избирательского корпуса. В самом же блоке ХДС/ХСС Меркель приобрела черты безальтернативного германского вождя - в силу отсутствия в руководстве христианских партий ярких политиков, способных составить ей настоящую конкуренцию (причем она лично приложила руку к созданию такой ситуации). Сама судьба, казалось, 
благоволила к Меркель - бури и невзгоды, время от времени обрушивающиеся на Евросоюз, обходили ее и управляемое ею государство стороной. Экономика ФРГ крепла вопреки нарастанию кризисных явлений в других европейских странах. Германия все основательнее закреплялась на позициях неоспоримого лидера интегрированной части Европы.

Начались изменения и в сфере внешней политики - постепенно и почти незаметно, как всегда у А. Меркель. Поначалу основные элементы преемственности не были затронуты, по крайней мере формально. Но очень скоро стало ясно, что за борт выброшено главное внешнеполитическое достижение эры Шредера - тихо скончался неформальный «треугольник» Париж-Берлин-Москва, возникший после того, как эти три столицы отказались одобрить американскую интервенцию в Ираке. Для Меркель существование подобной трехсторонней конструкции было абсолютно неприемлемым, поскольку носило по существу характер вызова глобальным амбициям США, настаивавшим на своем праве управлять миром. Она не могла также смириться с тем, что «треугольник» мог означать преодоление последствий холодной войны на европейском континенте, - для нее, как и для Вашингтона, холодная война еще не достигла своей главной цели: ликвидации российского влияния в мире; в ее глазах Россия продолжала оставаться глобальным противником [См.: Максимычев, 2014; 2018].

Если для Г. Шредера свободный механизм франко-германо-российских консультаций был равнозначен заявке на признание самостоятельности Европы в качестве глобального центра влияния, то А. Меркель больше всего опасалась утратить доверие США и осложнить тем самым германо-американские отношения. Она не верила в способность Евросоюза утвердиться в роли равноправного игрока на мировой арене, а главное - в возможность для Германии сохранить в таком случае ведущие позиции на континенте: ведь большинство членов Евросоюза следовали указаниям из Вашингтона. В американской же тени, по ее убеждению, ФРГ вполне может рассчитывать на полномочия своего рода прокуратора европейской провинции.

Вассальная преданность Соединенным Штатам была для нового канцлера безусловным политическим стержнем. Даже тесные отношения с Францией, без которых германское верховенство в Евросоюзе было бы немыслимым, занимают подчиненное место в ее представлениях о глобальном миропорядке. В этом сказывается не только признание роли США как высшего главы Запада и тем самым «владыки мира»; здесь просвечивают также личные воспоминания А. Меркель о трагическом конце ГДР, когда горбачевская Москва с готовностью и в ущерб себе предала своего важнейшего стратегического союзника в Европе. Именно тогда у будущего канцлера сложилось убеждение, что в конфликте с США Россия придет в конце концов к тому, чем завершил свое существование СССР: капитулирует и развалится. Делать ставку на того, кто непременно проиграет, не отвечает сугубо практической немецкой натуре. $\mathrm{K}$ тому же не стоит забывать об уходящем корнями глубоко в германскую историю «натиске на Восток» - Дранг нах Остен. 
В руководящих кругах ФРГ, опьяненных неожиданной триумфальной «победой» над СССР, позиция А. Меркель не выделялась оригинальностью. Логика рассуждений, основанных на презумпции разгрома объединенным Западом восточного гиганта в холодной войне, была с готовностью воспринята всем германским политическим классом. Как и канцлер, большинство германских «властителей дум» полагали, что ФРГ в качестве верного союзника США открыт путь к командным высотам второго уровня сначала в Западной Европе, затем на всем европейском континенте и, наконец, в глобальном масштабе. Первые попытки замены столь блестяще оправдавшей себя «новой восточной политики» Вилли Брандта возведением нового «санитарного кордона» вдоль западных рубежей России относятся к временам правления Г. Коля. Учреждение в августе 1991 г. Веймарского треугольника в составе ФРГ, Франции и Польши отражало начавшуюся перестройку стратегического мышления немцев, выражавшуюся, в частности, в требовании: «Ни одного соглашения с Россией без предварительного одобрения Польшей». Мало кого в ФРГ тогда смущало, что выполнение этого требования означает в действительности демонстративное игнорирование интересов Советского Союза / Российской Федерации.

Перевод внешней политики ФРГ на антироссийские рельсы занял определенное время. При Г. Коле возведение польских интересов в ранг приоритета, что неизбежно создавало тормоз на пути развития отношений с Россией, лишь намечалось, а при Г. Шредере было и вовсе оттеснено на задний план - именно при нем началась реализация проекта газопровода «Северный поток», против которого шумно протестовали поляки. А вот А. Меркель начала демонтаж политических отношений с Россией сразу же после прихода к власти. Она с порога официально объявила отношения с непосредственными соседями ФРГ своим абсолютным приоритетом. Конечно, при ней был введен в действие «Северный поток-1» и начато сооружение «Северного потока-2», но это диктовалось не стремлением к укреплению российско-германских отношений, а совершенно конкретными, императивно заявленными германскими хозяйственными нуждами.

Резко изменилась атмосфера предусмотренных в договорном порядке российскогерманских встреч на высшем и министерском уровне. Постоянно проявлялись попытки Берлина вмешиваться во внутренние дела РФ, используя тему защиты прав человека. Вошли в практику приемы, демонстративно устраиваемые Меркель для представителей «внесистемной» прозападной оппозиции в России. Созданный Владимиром Путиным и Герхардом Шредером «Петербургский диалог» как площадка для всесторонних контактов и дискуссий по актуальным проблемам внутреннего и международного развития стал походить на фехтовальный зал, где соревнующиеся стремятся как можно более чувствительно «уколоть» другую сторону.

Деструктивный фон российско-германских отношений, созданный германской стороной при А. Меркель, делает понятными причины резко враждебной реакции ФРГ на воссоединение Крыма с Россией, хотя кому как не немцам должен быть понятен моральный и правовой контекст этого исторического события - воссоединившейся Германии еще не исполнилось и 30 лет. Крым и гражданская война на Донбассе яви- 
лись для Берлина не причиной, а поводом для организации похорон конструктивного сотрудничества с Россией. Общепризнанная роль германской дипломатии в подготовке и реализации государственного переворота на Украине в феврале 2014 г., а также во введении Евросоюзом антироссийских санкций не оставляет сомнений в том, что замораживание отношений с проводящей независимую политику Россией было давней целью ориентированной на укрепление союза с США политики А. Меркель, поддержанной социал-демократами.

\section{Кризис}

Долгий период успешности подталкивает, как правило, к усыплению бдительности и росту соблазна игнорировать реальность. $\mathrm{K}$ тому же синдром отличника плохо сочетается со способностью адекватно оценивать возможные зигзаги труднопрогнозируемых процессов. В 2016 г. Ангела Меркель пошла ва-банк, поставив все на победу Хиллари Клинтон на президентских выборах в США. Для нее, уже предвкушавшей американо-германскую гармонию в деле совместного управления делами Запада, избрание Дональда Трампа было равнозначно удару в солнечное сплетение. Шок оказался тем болезненнее, что наложился на потрясение, вызванное недооценкой канцлером силы протестной реакции немцев на иммиграционный кризис.

Обе ошибки были обусловлены тем, что А. Меркель пропустила момент, когда кризис американского глобализма перерос в его катастрофу и в международную политику стал возвращаться принцип национальной самоидентификации. Не одна она проявила подобную близорукость. Большинство представителей европейского политического класса также не поняли, что достигнута «точка невозврата», что массовый протест против навязывания извне чужой воли превратился в определяющий фактор развития внутренней обстановки в странах Евросоюза. Неожиданно для них лицемерие, с которым элиты еще недавно успешно оправдывали все творимое ими, ссылаясь на западные или европейские ценности, стало все чаще восприниматься гражданами именно как лицемерие и ничего больше. Люди перестали воспринимать призыв жертвовать национальными интересами во имя чего-то, что на поверку всегда оказывалось нужным только американской либеральной империи или управляемой из-за океана бюрократии ЕС. Универсальная дубинка для дисциплинирования союзников США сломалась, когда Д. Трамп с его лозунгом «Америка превыше всего!» нанес удар, так сказать, в спину глашатаям «общих ценностей».

По ряду исторических и психологических причин национальный ренессанс особенно остро сказался на ситуации в ФРГ. С 1945 г. немцам (особенно западным) усиленно внушали: все, что связано с понятием «нация», неприемлемо и предосудительно, потому что в прошлом в Германии существовал преступный режим, претендовавший на титул национального (точнее, национал-социалистского), и все, что можно было бы назвать национальными интересами немцев, должно по этой причине быть подчинено общим интересам Запада. В ГДР дело с общими интересами Востока обстояло не так однозначно, поскольку интернационалистская философия марксизма провозглашала не отмену, а гармонию национальных интересов строящих социализм народов. 
Отчасти и поэтому восточные немцы гораздо свободнее оперировали понятиями нации и национальных интересов.

Вопреки привычным штампам, ГДР, в отличие от Западной Германии, во многом сохранила традиционную немецкую культуру со всеми ее сильными и некоторыми слабыми сторонами. Вальтер Момпер, видный представитель СДПГ, правящий бургомистр (Западного) Берлина в 1989-1990 гг., зафиксировал в своих мемуарах: «В то время как у большинства западных немцев было лишь туманное представление о жизни немцев в ГДР, западные берлинцы доподлинно знали, что происходит в [советской] “зоне“. Я тоже охотно посещал ГДР, мне нравились земля и люди. Им приходилось жить в безрадостном окружении. Города и дома были серыми, модерн и блеск Запада отсутствовали. С другой стороны, ГДР не была так американизирована, так унифицирована на западный манер, как ФРГ. Все выглядело намного более немецким, более приземленным и более преходящим. Для меня поездки в ГДР всегда были поездками также и в германскую историю» [Momper, s. 150-151].

Именно восточные, а не западные немцы выступили в качестве инициаторов присоединения ГДР к ФРГ в 1989-1990 гг. Однако Западная Германия постаралась облачить процесс поглощения Восточной не в национальные, а в антикоммунистические одежды. И только затопившие в последние годы Германию миллионные потоки новых мигрантов из охваченных не без участия Запада войнами регионов планеты и связанное с этим обострение криминогенной обстановки в прежде идиллически спокойных немецких городах и весях вернули национальную проблематику в общественный дискурс. К всеобщему удивлению оказалось, что и западные немцы не только не забыли, но и не собирались забывать, что в Германии существует такая же нация, как и другие нации, с теми же правами и интересами, что и у всех.

После того как А. Меркель приветствовала массовое прибытие иммигрантов, заявив: «Мы справимся!» [Sommerpressekonferenz...], ее харизма рухнула. До немцев дошло, что непогрешимая канцлер может допускать неверные шаги. Для огромного сектора избирательного корпуса ФРГ она перестала быть «германской мамочкой» и превратилась в «хромую утку».

Неизвестно, было ли самостоятельным или подсказанным решение А. Меркель не выдвигать свою кандидатуру на выборах председателя ХДС на очередном съезде партии в декабре 2018 г. Во всяком случае, оно логически вытекало из сложившейся негативной ситуации. Пару лет назад ее намерение завершить в ближайшее время политическую карьеру вызвало бы смятение и великий плач по всей Германии, поскольку сама мысль о том, что канцлером будет не А. Меркель, представлялась большинству избирателей почти святотатственной. Теперь ничего подобного не наблюдалось. Были сразу заявлены кандидаты в преемники действующего председателя ХДС, и началось деловое обсуждение их шансов одержать верх.

Пробил час подведения итогов длившегося практически полтора десятилетия правления пока что единственной женщины на посту главы германской исполнительной 
власти. Ей предшествовала череда выдающихся государственных деятелей, первым из которых был «железный канцлер» Отто фон Бисмарк, создавший современную Германию. Его овеянная легендами незаурядная фигура до сих пор остается точкой отсчета при определении степени успешности политиков, берущихся управлять немцами. По преданию, Бисмарк завещал немцам на все времена осмотрительное отношение к России. Передают его слова: «Заключайте союзы с кем угодно, развязывайте любые войны, но никогда не трогайте русских». До сравнения с Бисмарком масштабы Меркель не дотягивают. Ее вклад в присоединение ГДР к ФРГ незначителен, и ей не удалось устранить различия между восточными и западными немцами. Но самое главное: она не вняла совету Бисмарка по части германо-российского сотрудничества.

Во внутриполитической сфере результаты «эры Меркель» выглядят разнонаправленными. К числу ее успехов можно отнести впечатляющее ослабление влияния социал-демократов. За время «больших коалиций» СДПГ растеряла практически все свои позиции в политической жизни страны, хотя еще при Г. Коле она продолжала играть роль главного соперника ХДС/ХСС. Сейчас в рейтинге избирательных симпатий социал-демократы идут наравне с новыми правыми из «Альтернативы для Германии» (АдГ) или даже уступают им. Конечно, вряд ли стоит вменять это обстоятельство в заслуги одной А. Меркель. Все европейские социалисты переживают сейчас острейший кризис - стоит только посмотреть на французских коллег СДПГ, которые к концу президентства своего однопартийца ушли в политическое небытие'. Но усилия Меркель по вовлечению в орбиту влияния христианских партий среднего класса, на интересы которого ориентируется также СДПГ, несомненно, способствовали таким результатам.

В то же время именно повышенное внимание, уделяемое среднему классу, привело к оголению правого фланга ХДС/ХСС, на котором смогла развернуться «Альтернатива для Германии» (АдГ), возникшая и окрепшая на волне недовольства «исламизацией» ФРГ. А. Меркель сама распахнула двери для АдГ, обратившись к мигрантам из стран Ближнего Востока и Северной Африки с призывом приезжать и устраиваться в ФРГ. Не случайно Фридрих Мерц сделал одним из центральных пунктов своей предвыборной программы упрек в адрес руководства ХДС по поводу недооценки опасности, которую представляет собой АдГ. Но ответный ход его политических противников, объявивших Мерца «человеком вчерашнего дня», произвел сильное впечатление на партийный аппарат ХДС, который и решил в конечном счете, что новым председателем партии станет Аннегрет Крамп-Карренбауэр. Партийным аппаратчикам было что терять в случае победы Ф. Мерца, получившего неофициальный, но вполне оправданный титул «анти-

1 Экзистенциональные трудности, переживаемые европейскими социалистами, приводят к значительному обострению внутриполитической ситуации в странах Евросоюза. В частности, отсутствие социалистической (хотя бы по названию) альтернативы обусловило появление на улицах французских городов «желтых жилетов» со всеми вытекающими из этого последствиями. Можно только согласиться с редактором «Шпигеля» Яном Фляйшхауэром, который недавно констатировал: «Стабильность послевоенного демократического строя [ФРГ] всегда опиралась на прочность обеих его великих опор - досточтимого Христианского союза и еще более досточтимой Социал-демократии. Это отличало Германию от многих стран с более гетерогенной и тем самым намного более хаотичной партийной системой» [Fleischhauer]. 
Меркель» [см. напр.: Bauer]

Противоречивыми оказались и итоги внешнеполитической деятельности А. Меркель. Бесспорно, она упрочила руководящую роль ФРГ в Евросоюзе, чему способствовали дальнейшее ослабление позиций Франции при президенте Франсуа Олланде и продолжающаяся «детронизация» Великобритании, вызванная как отсутствием объективных предпосылок для того, чтобы играть роль великой державы, на которую она упорно претендует, так и недальновидностью британского политического класса, решившегося на Брекзит. Немцы высоко оценили заслуги А. Меркель в этой области, иной раз даже преувеличивая дипломатические способности канцлера (в частности, в рамках «Нормандского формата»). Например, не так давно журнал «Шпигель» писал: «Украинский кризис был первым значительным конфликтом в Европе после Второй мировой войны, урегулирование которого США предоставили европейцам - то есть Германии, Меркель. В условиях украинского кризиса она стала политиком глобального масштаба. Она вела переговоры с Путиным, в бесчисленных переговорах по телефону добивалась уступок с его стороны» [Hoffmann].

Однако положение ФРГ в качестве «хозяйки Евросоюза» приносит Германии не только плюсы. Оно вызывает также осложнения в ее отношениях с более слабыми странами EC, на которые Берлин упорно оказывает давление, безоговорочно требуя финансовой дисциплины и сокращения государственных расходов. Общественность переживающих экономические трудности стран возлагает непосредственно на Берлин ответственность за снижение своего жизненного уровня. Немцам охотно припоминают германские прегрешения в годы Второй мировой войны. Кое-где муссируется гипотетическая возможность дополнительной выплаты репараций за причиненный нацистами ущерб. Особенно болезненно немцы воспринимают подобные выпады со стороны поляков, которых А. Меркель собиралась сделать главным союзником ФРГ на Востоке Европы.

В целом образ Германии в глазах партнеров объективно ухудшается с каждым годом. Этот процесс сдерживается лишь тем, что финансовый вклад немцев является в конечном счете главным источником наполнения казны ЕС. ФРГ - хозяйка Евросоюза, пока ее экономика господствует в нем. С этой точки зрения проект «Северный поток-2», обеспечивающий на долгие годы вперед конкурентоспособность германской промышленности, является ключом к «светлому будущему» ФРГ. По логике вещей, добиваться срыва проекта должны те, кто хочет ослабления позиций Берлина. Пул противников «Северного потока - 2» возглавляют США, Украина, Польша - страны, которые А. Меркель рассматривает как ближайших союзников. Таким образом, мир для нее как бы перевернулся вверх тормашками.

Вопреки своим антирусским наклонностям, Меркель до сих пор не согласилась похоронить «Северный поток-2», - конечно, не из симпатии к России, а по требованию представителей бизнеса, ответственных за германскую экономику. Но кроме этого ей в сфере восточной политики нечем похвастаться. Охлаждение и формализация стали характерными для российско-германских отношений задолго до украинского кризиса. 
Участие министра иностранных дел ФРГ вместе с министрами иностранных дел Франции и Польши в международном прикрытии подготовки и проведения вооруженного путча в Киеве в феврале 2014 г. не было случайным.

Оторвать Украину от России и стравить их друг с другом было целью еще кайзеровской Германии. В 1918 г. германские и австро-венгерские оккупационные силы учредили после Брестского мира с Россией «независимую» Украину во главе с гетманом П.П. Скоропадским - в качестве германского протектората, которому они собирались передать почти половину европейской части России вплоть до северного побережья Каспийского моря. Тогда планам германского военного командования помешала капитуляция рейха, не столько потерпевшего поражение на полях сражения Западного фронта, сколько поспешившего предотвратить вступление иностранных войск на территорию Германии после народных бунтов в тылу. На получение статуса, подобного режиму Скоропадского, рассчитывали украинские приспешники Гитлера, объявленные майданной властью «героями нации». Киевский путч 2014 г. стал в определенной степени реализацией задумок, взлелеянных германскими генералами еще век назад.

Во всяком случае, действия ФРГ полностью укладываются в схему столетней давности. Нынешний украинский кризис был на сто процентов использован Берлином для развертывания русофобской кампании, А. Меркель стала главным мотором принятых Евросоюзом антироссийских санкций. Вот только все это в конечном счете не принесло ФРГ ожидавшегося политического выигрыша. Наоборот, произошло ослабление германских позиций, да и в целом позиций ЕС в международных делах. По инициативе Германии весь Евросоюз поставил себя в зависимость от украинского конфликта, от действий безответственного режима П.А. Порошенко, и осознание серьезной опасности этой ситуации пробивает себе дорогу, в том числе и в ФРГ. Тем более что заморозить Россию в «нулевом статусе» девяностых не удалось.

Мюнхенская речь российского президента (2007 г.) и «восьмидневная война» 2008 г. стали знаковыми событиями, ознаменовавшими возвращение России на мировую арену. Российское содействие в разгроме террористического «исламского государства» на территории Сирии и восстановлении там гражданского мира не оставило сомнений в способности и готовности Москвы выполнять глобальные обязательства. Это опровергло пророчество о «конце истории» в том смысле, что определяемый США монополярный миропорядок пришел навсегда. Мир остался многополярным. Но только признать эту истину и сделать практические выводы из такого признания оказалось невероятно трудно, практически невозможно для убежденных в своем превосходстве западных лидеров, одним из которых, несомненно, является А. Меркель.

\section{Ближайшие перспективы}

На важнейшем для дальнейших судеб партии съезде ХДС в Гамбурге в декабре 2018 г. А. Меркель еще раз продемонстрировала свои лучшие качества организатора-отличницы. Благодаря тщательно продуманной канцлером режиссуре, во вто- 
ром туре голосования председателем партии была избрана поддержанная ею Аннегрет Крамп-Карренбауэр, хотя и минимальным большинством - при почти тысяче делегатов ее главному сопернику Фридриху Мерцу не хватило для победы всего 19 голосов. АКК (как принято сокращать довольно сложное имя нового председателя ХДС) - это провинциальный политический деятель из Саара, в прошлом премьерминистр этой крошечной земли, около года занимавшая пост генерального секретаря ХДС, полученный ею по предложению все той же Меркель. Она рассматривается в германской политике как «копия» Меркель, ее «клон», «мини-Меркель» [См. напр.: Bauer; Hassel].

AКК пророчат повторение карьерного взлета ее покровительницы, начавшегося также с должности генерального секретаря партии. Но для этого ей необходимо отделить себя от А. Меркель, чтобы переломить связанную с именем нынешнего канцлера тенденцию потери симпатий избирателей, сохраняющуюся на протяжении последних избирательных кампаний. Решение этой сложнейшей задачи отнюдь не гарантировано. Избрание Крамп-Карренбауэр - выигрыш для Меркель, которой удалось таким образом отсрочить свою отставку с поста канцлера, возможно, до 2021 г. Станет ли оно выигрышем и для ХДС, которому предстоит преодолеть глубокие внутренние противоречия, - покажет время.

Нельзя сказать, что тема необходимых и неизбежных перемен в политике ХДС по всему спектру стоящих перед ФРГ проблем не присутствовала в дискуссиях, ведущихся в партии, в том числе и среди делегатов съезда 2018 г. Всеобъемлющий кризис партии очевиден для всех, пути его преодоления обсуждаются страстно и с небывалой резкостью. Двое из трех кандидатов на освобождавшийся пост председателя ХДС (Фридрих Мерц и Иенс Шпан) требовали путем решительного изменения профиля партии на важнейших направлениях политики ФРГ обозначить разрыв с «эрой Меркель», завершающейся не только провалами в сфере внутренней политики, но и внешнеполитическими неудачами. Предложенные ими шаги не поражали радикальностью и полетом творческой мысли, но могли служить показателем убеждения, что многое в германской политической реальности должно стать иным. В том числе и спокойная, будничная, но упорная манера Меркель вести даже самые острые и напряженные дела.

С А. Крамп-Карренбауэр во главе ХДС не приходится ожидать скорых и серьезных сдвигов в политике ФРГ. Между тем на обстановку в Германии влияет и общее обострение кризисных явлений в интегрированной части Европы. Под знаком неудач складывается политическая карьера также Терезы Мэй и Эмманюэля Макрона. Германскую общественность сильно обеспокоила атмосфера бунта на улицах французских городов, обусловленная протестом против, казалось бы, не столь значительной проблемы повышения налога на автомобильное топливо. В этой связи вспомнили, с какой легкостью студенческие волнения 1968 г. во Франции перекинулись на Западную Германию. Перспектива снижения жизненного уровня населения Великобритании в связи с «жестким» Брекзитом не добавляет немцам оптимизма. Видный германский дипломат, председатель Международной конференции по безопасности в Мюнхене Вольфганг Ишингер рисует тревожную картину на окружающем ФРГ пространстве: «В становя- 
щемся все более авторитарным и нелиберальным мире Европе придется еще настойчивее бороться за свои интересы и сохранение миропорядка, который приносил ей до сих пор огромный выигрыш» [lschinger, s. 253]. В ФРГ ширится осознание, что срочные изменения назрели по всей линии государственного управления. Вопрос в том, успеют ли политики, ответственные за положение дел в стране, принять превентивные меры, прежде чем недовольство людей выплеснется на улицы.

Очень может быть, что найти путь к преодолению возникшего тупика будет суждено новым политикам, ворвавшимся в германскую политическую жизнь на гребне массового протеста против несостоятельной глобалистской линии, проводимой совместно ХДС/ХСС и СДПГ. Феномен появления новых людей в европейской политике не ограничивается ФРГ. Ренессанс национальной идеи охватил большую часть Европы. Три четверти века не только немцев, но и всех европейцев убеждали в том, что нация и национальные интересы - это плохо и предосудительно, что мир стал «глобальным», что им руководит Вашингтон... Три четверти века европейцы послушно голосовали за партии, для которых термин «национальный» звучал как ругательство. И только потоки иммигрантов, переполнившие европейские города и поставившие под угрозу сохранение европейского стиля жизни, подвигли жителей Старого света на попытку разобраться в том, насколько справедливо и насколько соответствует их представлениям о добре и зле мироустройство, закрепляющее разбухание американской империи до размеров всего земного шара.

Именно с принципами американской империи несогласны те новые политические силы, которые несколько лет назад спонтанно появились практически одновременно во всех ведущих европейских странах. Они получили самые различные названия, звучащие подчас довольно экзотически - евроскептики, антиглобалисты, традиционалисты, популисты, крайне правые. По существу же все они более или менее аутентично отражают крутой поворот в общественном сознании большинства стран «старой» Европы, связанный с возвращением национального самосознания в европейскую политическую реальность в качестве защитной реакции на глобализм американского толка.

Против новых партий и объединений выступили в показательном единении все представители старого политического класса - правые, левые, либералы, консерваторы, националисты и т.д. В ход была сразу пущена тяжелая артиллерия - новых объявили родичами германского национал-социализма, хотя оснований для этого столько же, сколько для приравнивания социалистов к партии Адольфа Гитлера (кстати, такой прием действительно использовался в Западной Германии во времена Конрада Аденауэра). Ложность обвинения защитников национальных интересов в национализме легче всего доказать на примере отношения соответствующих партий к России: новые политики отвергают русофобию и считают сотрудничество с Россией единственным реальным способом обеспечить безопасность на европейском континенте.

Будущее за новыми партиями, поскольку только они предлагают путь, ведущий к прочному миру в Европе. Но когда их голос станет определяющим для политики каждой европейской страны, и прежде всего ФРГ, - предсказать трудно. Предстоящее 
завершение «эры Меркель» донельзя обострило постоянно стоящий перед Германией судьбоносный вопрос о ее месте в глобальной политике, и прежде всего о характере ее взаимоотношений с Россией, - вопрос, неудовлетворительное решение которого неоднократно ставило немцев в прошлом на край национальной катастрофы. Пока А. Меркель находится у руля германской политики, ждать существенного поворота не приходится. Но ее вероятным преемникам стоит задуматься уже сейчас. В конечном счете дело идет о судьбе Германии.

Сегодня ФРГ вновь на распутье. В который раз немцам приходится решать, должны ли они и могут ли позволить себе состоять в конфронтации с державой, без добрых отношений с которой невозможна безопасность ни в Европе, ни в мире. Остается надеяться, что поиски правильного решения в разумные сроки приведут к позитивному результату.

\section{Литература}

Максимычев И.Ф. Россия - Германия. Война и мир. От мировых катастроф к европейской безопасности. М. 2014.

Максимычев И. Падение Берлинской стены. Из записок советника-посланника Посольства СССР в Берлине. М., 2011.

Примаков: в бывшей Югославии все время будет «плавающая стабильность» // Вести. 25.03.2009. - URL: vesti.ru/doc.html?id=267070

Bauer U. Mini-Merkel, Anti-Merkel und Rebell // DW.ru. 02.11.2018. - URL: dw.com/de/minimerkel-anti-merkel-und-rebell/a-46127154 (date of access: 05.12.2018).

Fleischhauer J. Annegret Kramp-Karrenbauer: Frau von gestern // Spiegel. 29.11.2018. — URL: spiegel.de/politik/deutschland/annegret-kramp-karrenbauer-frau-von-gestern-kolumnea-1241038.html (date of access: 05.12.2018).

Hassel T. "AKK" - mehr als ein Merkel-Klon // tagesschau.de. 19.02.2018. — URL: tagesschau.de/ inland/kommentar-akk-101.html (date of access: 05.12.2018).

Hoffmann Ch. Merkels Vermächtnis steht auf dem Spiel // Spiegel. 29.11.2018. — URL: spiegel.de/ politik/ausland/ukraine-krise-angela-merkel-vermaechtnis-steht-auf-dem-spiel-a-1241016. html (date of access: 05.12.2018).

Ischinger W. Welt in Gefahr. Deutschland und Europa in unsicheren Zeiten. Berlin. 2018.

Maximytschew I. Russland begreifen. Berlin. 2018.

Merkel verteidigt Irak-Krieg // Frankfurter Allgemeine. 27.03.2003. — URL: faz.net/aktuell/politik/ cdu-csu-merkel-verteidigt-irak-krieg-189806.html (date of access: 05.12.2018).

Mit Helmut Kohl hätte es Jugoslawien-Krieg nicht gegeben: Willy Wimmer zum Tod des Altkanzlers // RT. 16.06.2017. — URL: deutsch.rt.com/inland/52517-kein-jougoslawien-krieg-mit-helmutkohl-willi-wimmer-zum-tod-des-altkanzlers/ (date of access: 05.12.2018).

Momper W. Grenzfall. Berlin im Brennpunkt deutscher Geschichte. Bertelsmann. München. 1991

Sommerpressekonferenz von Bundeskanzlerin Merkel // Die Bundesregierung. 31.08.2015. — URL: bundesregierung.de/breg-de/aktuelles/pressekonferenzen/sommerpressekonferenzvon-bundeskanzlerin-merkel-848300 (date of access: 05.12.2018). 